\title{
The Anti-Masters
}

\begin{abstract}
The author's reflections, which include an autobiographical note, focus on local research communities, that is, communities where the living scholarly discourse usually unfolds within one paradigm and the teachings of a Master which fill this paradigm. The starting point is the observation, referring mostly to the broadly understood humanities, that the discourse within a community which centres on a Master is sometimes imbued with the critical, sometimes even opposing narrations of anti-masters. In the primary relationship, the anti-masters and the Master confront each other as living people, as researchers who sometimes engage in an open debate and sometimes raise a dividing wall of critical silence. Taking into consideration the scale and the contents of these confrontations, the author distinguishes four categories of anti-masters. He also points out that the role of anti-masters in local research communities is often beneficial, especially from the long-term perspective. Their narratives may inspire and expand the community's scholarly horizons, including, as does occasionally happen, the views of wise Masters and their faithful disciples.
\end{abstract}

Keywords: local research community, living scholarly discourse, a Master, antimasters and their narrations.

\section{Antymistrzowie}

\begin{abstract}
Abstrakt
Nie unikając nuty autobiograficznej, autor poświęca swoje rozważania lokalnym wspólnotom badawczym, czyli wspólnotom, w których żywy dyskurs toczy się zwykle w obrębie jednego paradygmatu i wypełniającej go nauki Mistrza. Punktem wyjścia staje się tu obserwacja (odnosząca się głównie do szeroko pojętej humanistyki), że dyskurs wspólnoty skupionej wokół Mistrza niekiedy przenikają również - krytyczne czy wręcz opozycyjne - narracje antymistrzów. W relacji pierwotnej anty-
\end{abstract}

* Dr hab., Professor Emeritus at the University of Lodz. 
mistrzowie i Mistrz konfrontują się jako żywi ludzie: badacze czasem toczący jawne spory, a czasem oddzielający się polem krytycznego milczenia. Autor wyróżnia w związku z tym cztery kategorie antymistrzów, uwzględniając skalę i treść tej konfrontacji. Zwraca zarazem uwagę na to, że rola antymistrzów w lokalnych wspólnotach badawczych często bywa jednak, zwłaszcza w dłuższej perspektywie czasowej, pożyteczna. Ich narracje mogą inspirować i rozwijać naukowe horyzonty wspólnoty, także - co się zdarza - poglądy mądrych Mistrzów i ich wiernych uczniów.

Słowa kluczowe: lokalna wspólnota badawcza, żywy dyskurs naukowy, Mistrz, antymistrzowie i ich narracje.

\section{Master and anti-masters: from the life of local research communities}

The notion of "anti-masters" is unclear and ambiguous. As is the notion of "masters." I have no ambition to present a complete and final definition of either one. Instead, I prefer to adopt the strategy of conceptual sensitizing or-as Paul Willis characterized it-a strategy of hurling these concepts at the "real, tangible world" - at the world of academic research communities and their discourse-in order to find out if and how they fit this world (Willis 2005: 11).

I begin with a few interventions that will clear up the field of consideration. My observations are restricted to the field of humanities. In a broader sense-for Tadeusz Pawłowski as well as for me, and perhaps for many others-the humanities also incorporate social sciences. ${ }^{1}$ Perhaps some of the issues that I shall raise also refer to the natural sciences, or science in general. I would even dare to say that they most certainly do.

In the background of these observations we shall find-sometimes more, sometimes less pronounced-an autobiographical frame. However, even a hidden autobiographical vein is needed to bring the more general theoretical concepts, including typologies, closer to reality and to explore them on the basis of concrete personal experience, pertaining both to life and research. In my case, these experiences stems from the many years I have "spent" in the broadly understood humanities.

The notion of "anti-masters" is not semantically independent. It is impossible to talk about anti-masters without mentioning masters. The two elements: "anti-" and "masters" point to this themselves. Another relationship is more important. With my observations, I am encroaching into the centre of a lively community,

\footnotetext{
1 Tadeusz Pawłowski, whom I mention here, was my first-in the lively academic discourse-and only teacher of logic and the methodology of science. He would often use the terms "humanities in a broader sense" or "widely-understood humanities" during his seminars and other academic meetings. It also appeared in his publications (Pawłowski 1977: 33, 67; Pawłowski 1978: 145, 171). Equating humanities with social sciences, or separating them, has long been a methodological problem connected with the classification of science.
} 
energized by its own discourse. Perhaps-since it is the most convenient perspective for me-a local research community. ${ }^{2}$ I have joined many local communities during my biographical journey, representing many different academic disciplines. A local academic or research community is often engaged in a discourse centred around a single paradigm, replete with the teachings of a Master. For this reason it sometimes deserves to be called an "academic school" (especially if it is not limited solely to theorizing) or a "research school." Or it assigns this name to itself, for better or worse reasons; after all, it is associated with "the Master's teachings," his way of thinking influencing other members, starting with the empirical research conceptualized by him-the field research. Moreover, the community is also highly loyal to the Master not only with their minds but with their hearts. It is because the Master has charisma, or-as is repeated in the founding legend-has had it "since the beginning," and some of that charisma may still be left.

The anti-master always remains in a relation with the Master-or that is at least my point of view: he is "active" in the research community because of him. In the basic, primary relationship, he acts as a living person against another personliving close to each other on an everyday basis. In a secondary relationship, the anti-master acts against the figure of the Master, a figure distilled from his work and from the stories that were told, are still being told, about the Master. A more complex relationship exists when an anti-master positions himself against the Master with the help of other masters-chosen by himself, rarely with their consent-so-called "second-hand" masters, masters known from correspondence or from their books, most often "master figures" whom he does not know personally. In his work against the Master, therefore, the anti-master hides behind Jerzy Giedymin, Paul Ricoeur, Michel de Certeau, Clifford Geertz or Jacques Lacan, even though he never had the chance to engage with them outside of their texts. However, and although it is often difficult to confess, he has been intellectually seduced by their theoretical ideas. ${ }^{3}$ Indeed, personally-known and living masters

\footnotetext{
2 This is the most convenient perspective, since I have written about local academic communities on several occasions in the past (Wejland 2004; Wejland 2010).

${ }^{3}$ Shielding the anti-master by world-renowned Great Masters, or even by respected teachers and other authority figures, is always part of a confrontation with the local Master. Many events that happen in the life of a community do not fit this situation, although — as it would seem at first glance-they are precisely those types of events. A simple fascination with some Great Master, as well as the need to share this fascinations with others, including the Master, can happen without even the slightest tone of confrontation. Sometimes a fascinated adept may be inspired to "speak" in a specific manner - speak like Geertz, or Lacan, or someone else. I myself in the past for a long time "spoke like Giedymin." I was encouraged together with others to read the works of the logician and methodologist, especially his "Problemom, założeniom, rozstrzygnięciom," by Tadeusz Pawłowski in the period when he was interested in the logical theory of questions (mostly, admittedly, in the concepts of Nuel D. Belnap Jr.). My students sometimes engaged in "speaking" like James Spradley (in relation to the idea of participatory observation), Norbert Schwarz (because he would expand, e.g. through the logic of conversation, the old concepts of a questionnaire interview as a research situation) or Jacques Lacan (with the thought of reconstructing the foundations of psychoanalytical anthropology).
} 
can also shield the anti-master-other masters recognized by their local communities: in Warsaw, Cracow, Poznan... or anthropological, sociological, philosophical masters...

In the basic relationship, a living person interacts with another living person. Sometimes he is separated (artificially) from his scholarly writing. Other times it seems that it is easier to interact with his thought, or easier to do so with the person, when his teachings are difficult, hermetic in language and multifaceted to the point of becoming almost incomprehensible for students (perhaps the most faithful and persistent followers, studying with the Master for years, are able to understand it).

When the anti-master, acting against the Master in his local community, shields himself with (or hides behind) other "Great Masters," he can do so from the position of an aspiring local authority figure, even one who is anointed by the Master as his successor and heir. He can already be a "small master," assembling around him a group of followers, or simply people who are always open to collaborating with him, perhaps not yet dissidents when taking into consideration the mainstream discourse, the one connected with the Master and his academic achievements. The shield or cover that I am here referring to creates a peculiar triangle of confrontation: the "small master" positions himself directly against the Master, while also directly aligning himself (if only through reading) with the "Great Master," however, both masters are put side by side indirectly: he lays down the Great Master's achievements before the Master and expects a reaction. For example, with the popularity of American anthropology or sociology, our local Master will be confronted with the Great American Master. The "small master" will naturally serve the role of the judge in this confrontation, sometimes also wanting to get acclaim from others.

In a basic relationship, that is in a situation in which a person engages with another person, purely academic, cognitive conditions connected with the search for the Truth (or at least some kind of truths) do not exhaust this relation. Also the aesthetical dimension proves to be important. Someone who has "fallen in love" with a Master can easily "fall out of love," simply because the Master-seen in everyday, semi-private situations - turns out to be a person who slurps and chews loudly during meals. A dinner with him thus becomes a nuisance, even though it still remains a privilege, a cognitively-stimulating event. In a similar fashion, a master-miser also makes us uneasy: a scrooge and a niggard, someone who serves (not at all out of elegance) microscopic-sized canapés and liquors in almost invisible glasses. Instead of drawing us near, he discourages us. A master with lordly manners, unstable moods and unpredictable quirks is also someone who generates distance.

The aesthetical dimensions may be followed by a moral or ethical dimension. If the Master overly engages with his students, undeservingly singling out some while seemingly ignoring others, if you can only visit the Master under the condition of 
belonging to his court, if the Master is surrounded by an entourage of those who carry something for him or please him in other ways, then a "purely academic" evaluation is accompanied by a moral judgment, and the old style of following the Master-both literal and metaphorical-is subjected to revision.

What more can we say about masters? A brave master and a cowardly master-those are two very different people. A master who always stands behind "his own," and a master who avoids confrontation with his reviewers, a master who is open and kind, and a master who is hypocritical and jealous. A master who is eager to learn from his pupils, and one who is opposed to this kind of learning, especially one who thinks of himself as having all the answers, treating his students as though they have nothing interesting to say (at least when it comes to things concerning scholarship and academic research). A master who writes, who fills page after page with his writing, or an "oral" master, who in his writing requires the assistance of skilled and loyal pupils, but who conducts extensive and serious empirical studies, oriented at supplying his students with the necessary anthropological or sociological skills-an invaluable field scholar and teacher of "methodology."

There are different masters.

And there are different anti-masters.

\section{Types, or categories of anti-masters}

Generally, "anti-" means "against or in opposition to," as well as "oriented at competition or hostile," "different or opposite," that is, in defiance of something.

However, we can distinguish a few-easy to recognize-types, or categories of anti-masters. As is the case with types, when lined up together, they do not form any "satisfying" classification. In a looser construction of a typology, they will permeate with, and impose on each other. In the following interpretation, their characteristics will remain only a conceptual outline, merely a sketch of an image. It is also because-and that is the objective of the strategy of conceptual sensitizing -I do not wish to tighten or limit the space of their meanings, so as not to bind nor paralyze-as Herbert Blumer and Anselm Strauss were so keen on emphasizing - the thought that investigates the world with any definitive, predetermined refinements (see: Bokszański 1989: 125-126; Wejland 2013: 213-220).

The first type is of critics of Mastery in general. As a critic, an anti-master finds himself on the borderline of a "new" way of living in the academy, although still - since he is "acting" against the Master, a part of him exists in that which is "old." The anti-master wishes to abandon the ideal of scholarly (research) life in a traditionally-understood community, especially the local community, as well as in general the ideal of a traditional academic (research) community. The diagnosis he has imbued himself with or simply presented, is perhaps correct, although it is 
possible that he is wrong. Indeed, the anti-master may have already tasted postmodern, late-modernity ideas etc. He approves of individualism and independence from "so-called masters," he dreams of continuous mobility in the academic world, or he is already a nomad, critical of well-settled "old masters."

An anti-master of this type can be an anti-utopian. He considers the outdated ideal of communal life in science as utopian. However, he sometimes plunges into new utopias, approving other types of communities. For him, "mastery in general" can be an unobtainable perfection-unobtainable for "living people" in science, even those who are most outstanding. As a rule, this anti-master is insatiable, and he protests when someone unjustly calls him a master, therefore violating the rule of the elusiveness of mastery. His outrage does not have to be a result of modesty. Often it is someone who is opposing the "cult" of masters-an iconoclast, fighting against hysterical followers of masters, worshipers of their idealized image, conformists demanding honour and glory for the masters. It is therefore someone who is challenging the status of masters and their "cult" - the position of scholarly idols and the surrounding, unhealthy idolatry ${ }^{4}$.

At times the questioning of "mastery in general" can move beyond science (and scholarship), especially when it is understood in positivist terms, that is, in the old style or according to an old paradigm. With this gesture, the anti-master can however move into a domain of meaning-as Schütz understands it-other than science. In a field other than science, then, he can find "true masters" and a realization of the ideal of mastery-one that is, as he thinks, unobtainable in science. Literature, poetry, philosophy, politics, religion... Masters of these domains will oust so-called academic masters and challenge their mastery: not only in his private life, as it may seem at first glance, but also in the discourse of the research community inspired by the anti-master.

The second type are not opponents of mastery as such, but opponents of bad mastery. Examples of living masters or classic masters-bad masters, unsuccessful for this or another reason, can already be present in the discourse of the research community. However, the anti-master calls upon them in the context of his confrontation with the Master, who is still a local authority. Most often it is an insinuation or imputation. The image of the unsuccessful master from the past becomes a warning, both a request and an expectation that the Master will not follow in his steps. But perhaps it is already a critique of what the Master does. Rigidity in thought, the Master's clinging to his own outdated ideas, taken from the past; perhaps once meaningful, but today devoid of any taste of novelty. Schematic

\footnotetext{
${ }^{4}$ Here is an often repeated anecdote, that is a story based on real events. It exemplifies a thought — perhaps a bit clichéd by now, and turned into something banal after Thomas S. Kuhn - about the quasi-religious "cult" of the Master, and the treatment of his work as "sacred texts," that sometimes occurs in local research communities. One female follower of the thought of a neighbourly Master was so eager in imposing it on her local academic community, that her own So-So Master, during one meeting, finally lost his temper and shouted with irritation: “It is not the Bible, you don't have to stick to the letter!" The rest agreed with him in silence. No one dared to say it aloud.
} 
thinking which subordinates his pupils, non-creative convention, lack of shame in presenting the same thought over and over again. In a more or less direct fashion, the anti-master will oppose this, and often without showing any ambition to replace the Master or without exposing-if he even sees it in himself-the glimpses of his own mastery.

The anti-master, more or less openly, will also introduce examples of good mastery into the discourse of the community, especially the local one. They come from other research communities, and hold up their Masters as an ideal. Naturally, what the anti-master does may be accepted by his community or-more often-by some part of it, but it may also be denounced by them. The critique of "our" Master, or appraisal of "somebody's" Master, might be treated as a betrayal, or at least as something inappropriate. In that case, substantive arguments are replaced by emotional arguments. In this light, the sole act of criticizing becomes "unwarranted," "exaggerated," "immoral," or even "shameful." Because it may be linked with an appraisal of "others," it can be felt as an invitation for "unnecessary discussions," conflicts between local communities which "do not serve anybody."

The third type consists of different "independent souls." Rebellious figures, following their individual paths, insatiable, restless. Pushed by the current that dominates in the community into its peripheral streams, to the neglected, silenced niches. They are forced to the margins by the academic establishment, these outsiders who were once unrecognized-still living in the past, feeling as though they were harmed. They ironically describe themselves-as did Paul Willis-as scholars who conduct "an amateur theoretical methodology," perhaps as a result of being called "amateurs" in the past by the Masters, most often by those who represented the omnipotent rule of the positivist paradigm (Willis 2005: 11; italics in original). The Masters did not want to even acknowledge the novelty of the perspective or the originality of the method 6 . The anti-masters, hurt and rancorous, acting as if against the later recognition by the "academic world," in this way express their independence from the Masters and their emancipation in the community.

\footnotetext{
${ }^{5}$ When I was beginning my academic career, one of my teachers-still referred to by some today as a true Master of his Craft-put a truth in my head which I accepted but, perhaps out of naivety, did not want to remember: "science is jealous." Sometimes I had to remind myself of this truth. The aforementioned So-So Master could not hide his jealousy after I had submitted a long review of an excellent, although difficult book written by a Great Master from an academic community other than ours. I can still recall his words, full of grievances, that in my review I was "pursuing Ixology" "Ix" being the name of the Great Master). Meanwhile, my review was honest and-as it turned out some time later-my opinion was backed up by the majority of the academy. "Pure science" and "scientific life" are two different spheres, occasionally intersecting in painful ways.

${ }^{6}$ For the considerations I am pursuing in this paper, some allusive comments made many years ago by Paul Willis about his situation in the academic community are particularly significant. They can be found in various excerpts from his "The Ethnographic Imagination," while the introduction to that book presents them in a concise way, clearly highlighting their meaning (Willis 2005: 9-21). I wrote about Paul Willis's revelatory attitude in one of my articles (see: Wejland 2016: 40-46).
} 
"Young angry men," "revolutionists by nature," rebels, raised by the community as if-George Balandier would certainly agree- "vipers in her womb" (Balandier 1984). But, in addition, also "grey eminences," often academically weak and in no way motivating for their students, bitter dissidents, eager to challenge their Master, waging silent hit-and-run wars against them. Here it is also worth mentioning "Dark Masters"-above average in their scholarship, excellent or genius, who have parted ways with their Master, and are now incidentally or systematically "attacking" the Master and his community from the side, that is, from its periphery. Or from outside of its always moving borders.

The fourth type are anti-masters who are tolerated, or even liked by the Master and the community, who we could call-perhaps with a bit of an exaggeration-tricksters, keen on shrouding themselves in "myths" and "legends." They specialize in banter with the Master, a game-humorous, but at the same time serious, a conflict that is staged and theatrical, in which the anti-master halfjokingly, half-seriously exposes the "sins" of the Master and forces him to make a public "confession." Here the anti-master often disguises himself as the culturallydeveloped and well-tested bundle of mischief, a prankster who embodies-when confronting the Master- "an alternative wisdom," or simply "common sense." He is however quick to respond to the Master's mistakes, offering sharp judgment ${ }^{7}$.

This type would also include "community saints" figures: academically-but perhaps not only-haunted, holy fools who pass important proclamations, silent, lost in thought or "eloquent" prophets.

Making fun of, humiliating, deprecating is often a popular weapon of enfants terribles-sometimes highly intelligent, as much as they are blunt. In reference to the Master and in the local community they may be seen as a "heritage" from the

\footnotetext{
${ }^{7}$ The anti-master, a joker opposing bad mastery, sometimes acts in disguise, or even insidiously. When the So-So Master and his diligent followers are no longer willing to consider signals coming from other members of the community, above all from those well-read and well-oriented in the new ideas introduced into the scientific world, the playful anti-master can choose to employ an eristic strategy known as "immoral jokes." These are jokes, because they conceal the seriousness of his helplessness with an illegible play and intrigue. For example, to those who only bow their heads to English-language sociology and anthropology, instead of factual arguments that have failed, they propose only ideas that may seem as though they are coming from there, but in reality are authored by ad hoc made up authority figures: Ben Cartwright or Phil Collins. However, they are immoral, because even if they seem to be noble, they are still a fraud. Cartwright and Collins, referred to in desperation, have nothing in common with sociology or anthropology, other than the fact that they have been the subject of popular culture scholarship - the first as a character from a once-popular western TV series, the latter as a progressive rock / pop singer-songwriter. The "immoral joke" is a game in which a bland smile - when the joke succeeds-appears only on the anti-master's concerned face. However, exaggerated over-confidence can sometimes deceive the anti-master himself. For example, if for the purpose of the joke, he uses-not being fully aware-an unspecified description relating to more than one designate in the world, he may find himself falling into his own trap. Such a description is e.g. the name "Michael Jackson." So absorbed in the act of making fun of the Master, the anti-master might fail to notice that although he wished to present the "authority" of Michael Jackson-composer and pop artist-he unwittingly also pointed to Michael Jackson, the father of existential anthropology, or some other serious thinker sharing the same name, who could indeed effectively serve the role of an authority figure in humanistic discourse.
} 
Master's Master: a problematic inheritance, but accepted (for a time) without any protests. They are not always rowdy and shady-looking individuals, but more often what we call "sacred cows."

\section{Problems with anti-masters and benefits from anti-masters}

For the narrative that dominates in a research community, the narratives of the anti-masters, if they are not perceived as a scandal or danger, are more certainly a serious problem. The narratives of the anti-masters disorient and introduce uncertainty. They often add a specific, mysterious "what is more..." or "moreover..." —not always guaranteeing success, but not always ending with failure.

It is said (and indeed someone once told me this) that wise Masters always leave an open door and an invitation for the anti-masters: in order for them to -well, perhaps slightly more delicately-inspire them and their community with their critique, to encourage brave academic and research initiatives, to inspire a "well understood," creative and horizon-expanding infidelity to the old ideas.

In the academic and research communities of discourse, anti-masters serve a specific role; in the longer run and in a broader sense-a very useful role. They are often fascinating figures. Or at least for the time that they are indeed considered anti-masters, and have not yet transformed into masters. Or into "mutes," silently reminiscing on their "anti-mastery." Because you may be an anti-master, but more often you become one only for a time. Under specific biographical conditions: against the Master and the entire community.

\section{References}

Balandier G. (1984) Ład tradycyjny i kontestacja, transl. by J. Kurczewski in: J. Kurczewska \& J. Szacki (Eds.), Tradycja i nowoczesność, Warszawa, Czytelnik: 179-212.

Bokszański Z. (1989) Tożsamość. Interakcja. Grupa. Tożsamość jednostki w perspektywie teorii socjologicznej, Łódź, Wydawnictwo Uniwersytetu Łódzkiego.

Pawłowski T. (1977) Pojęcia i metody współczesnej humanistyki, Wrocław-Warszawa-Kraków-Gdańsk, Ossolineum.

Pawłowski T. (1978) Tworzenie pojęć $i$ definiowanie $w$ naukach humanistycznych, Warszawa, Państwowe Wydawnictwo Naukowe.

Wejland A. P. (2004) Jak żegnać lokalne paradygmaty. O metodologii wywiadu i naukowych wspólnotach dyskursu, "Kultura i Społeczeństwo", 1: 207-220. 
Wejland A. P. (2010) Dyskurs i tożsamość. Opowieści we wspólnocie naukowej in: Okolice socjologicznej tożsamości. Księga poświęcona pamięci Wojciecha Sitka, I. Taranowicz \& Z. Kurcz (Eds.), Wrocław, Wydawnictwo Uniwersytetu Wrocławskiego: 155-182.

Wejland A. P. (2013) O definiowaniu $w$ humanistyce - między retoryka a etykq in: Nie tylko o wsi... Szkice humanistyczne dedykowane Profesor Marii Wieruszewskiej-Adamczyk, D. Kasprzyk (Ed.), Łódź, Wydawnictwo Uniwersytetu Łódzkiego: 197-225.

Wejland A. P. (2016) Spojrzeć na świat jak antropolog. Wyzwanie autobiograficzne in: Auto/biograficzne aspekty praktyk poznawczych, M. Kafar (Ed.), Łódź, Wydawnictwo Uniwersytetu Łódzkiego: 33-47.

Willis P. (2005) Wyobraźnia etnograficzna, transl. by E. Klekot, Kraków, Wydawnictwo Uniwersytetu Jagiellońskiego. 